\title{
Special Issue from the International Conference on Molecular Recognition, Pécs; and Regional Biophysics Meeting, Balatonfüred; August 2007
}

\author{
Miklós Nyitrai · György Panyi
}

Published online: 21 October 2008

(C) European Biophysical Societies' Association 2008

\section{Erratum to: Eur Biophys J (2008) 37:1083-1084 DOI 10.1007/s00249-008-0360-6}

The title of the preface of the special issue published in September 2008 (volume 37, number 7) was incomplete due to an error that occurred during the edition process.

The correct title for the preface is "Special Issue from the International Conference on Molecular Recognition,
Pécs; and Regional Biophysics Meeting, Balatonfüred; August 2007; Guest editors: Miklós Nyitrai and György Panyi".

The guest editors regret this mistake and apologize to the contributors of the volume and the organizers of the Regional Biophysics Meeting.

The online version of the original article can be found under doi:10.1007/s00249-008-0360-6.

\section{Nyitrai}

Department of Biophysics,

Chairman of the Organizing Committee,

International Conference on Molecular Recognition,

University of Pecs, Pecs, Hungary

\section{G. Panyi ( ()}

Department of Biophysics and Cell Biology,

Member of the Organizing Committee,

Regional Biophysics Conference,

University of Debrecen, Debrecen, Hungary

e-mail: panyi@jaguar.dote.hu 